WITOLD FILIPCZAK

Uniwersytet Łódzki

iD ORCID ID: 0000-0001-5953-2480
WŁADZA I POLITYKA

W CZASACH NOWOŻYTNYCH

DYPLOMACJA I SPRAWY WEWNĘTRZNE

\title{
Polsko-moldawski konflikt handlowy w latach 1780-1785 a polityka wewnętrzna Stanisława Augusta Poniatowskiego
}

The Conflict over trade between Poland and Moldavia in 1780-1785 in the light of domestic policy of Stanisław August Poniatowski

$\mathrm{P}$ olsko-mołdawskimi sporami handlowymi w latach osiemdziesiątych XVIII w. zajmował się Jan Reychman, najszerzej w artykule z roku $1951^{1}$. Wspominano o nich także na marginesie rozważań o inicjatywach mających na celu rozwój handlu czarnomorskiego. Zagadnienie to było już prezentowane w literaturze przedmiotu (pisali o tym m.in.: Marek Mądzik, Zenon Guldon, a ostatnio Tadeusz Srogosz ${ }^{2}$ ), więc pominę jego szerszą prezentację. Ustalenia dawnej literatury rumuńskiej związane z interesującą mnie problematyką szeroko wykorzystał we wspomnianym artykule Reychman. Ograniczę się więc do krótkiego omówienia najbardziej istotnych spośród późniejszych publikacji pochodzących z tego kręgu językowego. Sporo informacji o konflikcie hospodarstwa z Rzecząpospolitą, a zwłaszcza o jego politycznych konsekwencjach, można znaleźć w pracach rumuńskiego historyka Veniamina Ciobanu, zwłaszcza w monografii dotyczącej relacji rumuńsko-polskich (w latach

${ }^{1}$ J. Reychman, Zatarg handlowy polsko-turecki o handel wódkq w XVIII w., „Roczniki Dziejów Społecznych i Gospodarczych / Annales d'Histoire Sociale et Économique” 1951, t. XIII, s. 215-228. Por. też idem, Życie polskie w Stambule w XVIII wieku, Warszawa 1959, s. 182-192.

2 M. Mądzik, $Z$ dziejów polskiego handlu na pobrzeżu Morza Czarnego w końcu XVIII w., „Annales Universitatis Mariae Curie-Skłodowska” 1973, Sectio F, vol. XXVIII, s. 205-224; idem, Powstanie i pierwsze lata dziatalności Kompanii Czarnomorskiej (1782-1785), „Rocznik Lubelski” 1979, t. XXI, s.77-91; Z. Guldon, Handel Polski z Motdawia, Nowoserbia i z Chersoniem w końcu XVIII w., [w:] Polska, Prusy, Ruś. Rozprawy ofiarowane prof. zw. dr. hab. Janowi Powierskiemu w trzydziestolecie pracy naukowej, red. B. Śliwiński, Gdańsk 1995, s. 57-61. Szersze zestawienie literatury przedmiotu w: T. Srogosz, Między wojna a modernizacja. Studia z dziejów kresów potudniowo-wschodnich Rzeczypospolitej w XVII-XVIII wieku, Częstochowa 2016, s. 217-218. 
1699-1848)3. Autor ten wcześniej opublikował artykuł o mołdawsko-polskich stosunkach handlowych w wieku XVIII ${ }^{4}$. W ostatnim czasie stosunki gospodarcze Mołdawii z Rzecząpospolitą były analizowane przez mołdawskiego badacza Valentina Arapu. W 2016 r. opublikował on artykuł o mołdawsko-polskich konfliktach ekonomicznych w II połowie wieku XVIII 5 . W roku 2019 Arapu przedstawił rozprawę doktorską dotyczącą relacji handlowych Mołdawii z Polską w tym samym okresie ${ }^{6}$.

Chciałbym krótko wyjaśnić ramy chronologiczne tekstu. W 1780 r. powracającego z Turcji Antoniego Dzieduszyckiego w roli nieoficjalnego reprezentanta Rzeczypospolitej w Stambule zastąpił Stanisław Pichelstein, tłumacz (dragoman) i szef polskiej szkoły języków orientalnych, którego zabiegi stanowiły nowy etap w działaniach polskich władz wobec Mołdawii?. Warto również wspomnieć, że w tym roku przybył do Polski Pierre Laroche, aby zbierać na potrzeby władz francuskich informacje o polskim potencjale w odniesieniu do handlu czarnomorskiego. Był on także agentem hospodarów mołdawskich, zaś jego misja miała cele wywiadowcze ${ }^{8}$. Końcowa data to pierwsze tygodnie 1785 r., kiedy nastąpiła zmiana na tronie mołdawskim. Aleksandra Mavrocordata I (syna Konstantyna) zastąpił w styczniu tegoż roku Aleksander Mavrocordat II (syn Jana) ${ }^{9}$, co nie zakończyło konfliktu, ale później budził on już mniejsze zainteresowanie.

Omówię teraz, jak wyglądała, będąca kluczowym źródłem wiedzy o omawianym zagadnieniu, korespondencja władz polskich z Pichelsteinem. Zagadnienie to wymaga wyjaśnienia, gdyż informacje zawarte w artykule Reychmana nie zawsze są precyzyjne. Wynika to z faktu, że większość listów wysyłanych z Warszawy jest znana z wersji niepodpisanych (minuty, ekscerpty itp.). Dysponujemy jednak dodatkowymi wiadomościami, które pozwalają ustalić miejsce ich powstania. Zasady prowadzenia dalszej korespondencji Pius Kiciński przekazał Pichelsteinowi 21 maja i 7 czerwca roku $1783^{10}$.

3 V. Ciobanu, Relațiile politice româno-polone între 1699 şi 1848, București 1980, s. 140-145.

${ }^{4}$ Idem, Aspecte ale relațiilor comerciale dintre Moldova şi Polonia in secolul al XVIII-lea., „Anuarul Institutului de Istorie şi Arheologie A.D. Xenopol” 1971, t. VIII, s. 119-144.

${ }^{5}$ V. Arapu, Componenta conflictuală a raporturilor economice dintre Țara Moldovei şi Polonia (a doua jumătate a secolului XVIII), „Studia Universitatis Moldaviae” 2016, nr 10(100), Seria „Ştiințe umanistice", s. 83-90.

${ }^{6}$ Idem, Relatiile comerciale dintre Moldova şi Polonia in a doua jumătate a secolului al XVIII-lea (Teză de doctor în istorie), Chişinău 2019 (nieopublikowana praca doktorska w formacie pdf).

7 J. Reychman, Życie polskie, s. 50, 67. Na temat Pichelsteina por. też Z. Abrahamowicz, M. Czaplińska, B. Grosfeld, Pichelstein (Pilsztyn) Stanistaw Kostka, [w:] PSB, t. XXXI, Wrocław-Warszawa-Kraków 1981, s. 28-30.

${ }^{8}$ J.A. Wilder, Traktat handlowy polsko-pruski z roku 1775. Gospodarcze znaczenie utraty dostępu do morza, Oświęcim 2016 (reedycja z 1937), s. 191-192; M. Mądzik, Powstanie i pierwsze, s. 77-79.

9 A. Stourdza [Sturdza], L'Europe orientale et le rôle historique des Maurocordato, 1660-1830, Paris 1913 , s. $245,255-256$.

${ }^{10}$ P. Kiciński do S. Pichelsteina, Warszawa, 21 V i 7 VI 1783, AGAD, ZP, sygn. 394, s. 51-52, 69 (dalszy ciąg listu 7 VI). Osobę, która napisała listy można łatwo zidentyfikować ze względu na informa- 
Kiciński pisał, że to on ma kontynuować korespondencję Gabinetu z placówką stambulską. Pichelstein dotychczas kierował listy do pisarza wielkiego koronnego Adama Cieciszowskiego, szefa Gabinetu Stanisława Augusta, który zmarł 19 maja roku $1783^{11}$. Korespondencja do Gabinetu miała być jednak wysyłana w kopercie, której adresatem był król' ${ }^{12}$. Tak więc przechowywaną dziś w Zbiorze Popielów (sygn. 398 i 399) korespondencję między Pichelsteinem a Gabinetem Reychman błędnie identyfikował jako prowadzoną z Departamentem Interesów Cudzoziemskich ${ }^{13}$. Tą ostatnią szef szkoły orientalnej miał wymieniać nadal z jego sekretarzem (od 1781 r.) Dzieduszyckim. Jak pisał Kiciński, miała toczyć się „po dawnemu, ale i cożkolwiek więcej możesz w osobnych aneksach rozszerzać się w ekspedycyjach pod imieniem jego adresowanych”. Sprawy „najdelikatniejsze i ściślejszego sekretu wyciągające” Pichelstein powinien kierować bezpośrednio do $\mathrm{króla}^{14}$.

Krótkiej prezentacji wymagają ponadto początki konfliktu. W 1778 r. hospodar Konstantyn Moruzi wprowadził zakaz importu polskich wódek do Mołdawii ${ }^{15}$. Moruzi objął władzę w Jassach po zamordowanym przez Turków w październiku 1777 r. Grzegorzu (Grigore) Ghice ${ }^{16}$. Jednak znane mi źródła z końca lat siedemdziesiątych XVIII w. sprawy konfliktu polsko-mołdawskiego nie eksponują, a koncentrują się na

cję, że Cieciszowski był stryjem żony autora. Por. Z. Anusik, Organizacja i funkcjonowanie polskiej stużby zagranicznej w latach 1764-1792 (Próba nowego spojrzenia), „Acta Universitatis Lodziensis. Folia Historica” 1996, z 58, s. 55. M. Rymszyna (Gabinet Stanistawa Augusta, Warszawa 1962, s. 115-116) podała nieściśle, że Kiciński był mężem siostrzenicy Cieciszowskiego.

${ }^{11}$ P. Kiciński do S. Pichelsteina, Warszawa, 21 V 1783, ZP, sygn. 394, s. 51-52.

12 P. Kiciński do S. Pichelsteina, Warszawa, 7 VI 1783, AGAD, ZP, sygn. 394, s. 52. W liście Kicińskiego z $21 \mathrm{~V}$ czytamy, że ma on prowadzić korespondencję ze Stambułem „póki Najjaśniejszy Pan nominować nie będzie przyszłego szefa Gabinetu swego". Kiciński faktycznie kierował Gabinetem, choć oficjalnie uzyskał awans na to stanowisko w maju 1786 r. Por. J. Michalski, Kiciński Pius, [w:] PSB, t. XII, s. $382-385$.

${ }^{13}$ J. Reychman, Zatarg handlowy, s. 219-221 (przypisy). Korespondencja z Departamentem Interesów Cudzoziemskich znajduje się m.in. w: AGAD, AKP, sygn. 83 (lata 1780-1785) i 84 (lata 17851787).

${ }_{14}$ P. Kiciński do S. Pichelsteina, Warszawa, 7 VI 1783, AGAD, ZP, sygn. 394, s. 52, 69.

15 J. Reychman, Zatarg handlowy, s. 215-216; J. Michalski, Dyplomacja polska w latach 1764-1795, [w:] Historia dyplomacji polskiej, t. II (1572-1795), red. Z. Wójcik, Warszawa 1982, s. 597. Według Arapu (Relatiile comerciale, s. 127) zakaz został wydany jesienią 1779 r. Wiadomość ta budzi wątpliwości, gdyż już wcześniej podjęto starania o jego zniesienie.

${ }^{16}$ Listy Jana de Witte, jenerata majora wojsk koronnych (1777-1779), wyd. S. Krzyżanowski, Kraków 1868, s. 1-3, 50; N. Jorga, Geschichte des Osmanischen Reiches: 5. Band - bis 1912, Nikosia 2017 (przedruk oryginału z 1913 r.), s. 26; M.C. Amăriuței, Grigore III Alexandru Ghica (abstract), Iaşi 2012, s. 7, 11 (streszczenie pracy doktorskiej w języku angielskim w formacie pdf). Według S. Grigoruță, Aspecte din viața și activitatea unui doctor de la curtea lui Grigore al III-lea Ghica, doctorul Fotache, „Anuarul Institutului de Istorie şi Arheologie A.D. Xenopol” 2014, t. LI, s. 85, Grzegorz Ghica został zamordowany 12 X 1777 r. (1 X według starego stylu). 
nieudanej misji Karola Boscampa-Lasopolskiego w Stambule (skąd został odwołany pod naciskiem Rosji) i poselstwie Numan-beja do Polski ${ }^{17}$. W czerwcu 1780 r. Stambuł opuścił zastępujący Boscampa-Lasopolskiego (po jego wyjeździe w 1778) Dzieduszycki, który próbował rozwiązać sprawę eksportu destylatów za pośrednictwem dyplomacji francuskiej ${ }^{18}$. We wrześniu roku 1779 Jean-Antoine Monet, agent Stanisława Augusta we Francji, otrzymał od króla zalecenie podjęcia zabiegów u ministra spraw zagranicznych Charlesa hr. Vergennes. Monet miał przekonać francuskiego polityka, by reprezentujący dwór wersalski w Stambule François hr. Saint-Priest wsparł polskie zabiegi dyplomatyczne. Chodziło w nich o wydanie przez władze tureckie polecenia Konstantynowi Moruziemu, by nie zabraniał sprzedaży polskich wódek w Mołdawii ${ }^{19}$. Stanisław August informował też swojego agenta we Francji, że czynił starania o poparcie polskich działań przez dyplomację rosyjską. Król liczył, że przedstawiciel Ludwika XVI będzie współdziałał z Dzieduszyckim i reprezentującym dwór petersburski Aleksandrem Stachiewem, jednak bez informowania posła rosyjskiego o współpracy polsko-francuskiej w tej sprawie ${ }^{20}$.

W końcu grudnia 1779 r. Saint-Priest wysłał list do hospodara, w którym pytał o powody wprowadzenia zakazu. Sugerował też, że Polska może podjąć kroki odwetowe, np. zacząć importować wino oraz sól z innych krajów ${ }^{21}$. Moruzi odpowiedział na pismo memoriałem, w którym uzasadniał swoją decyzję. Twierdził, że działał mimo żądań dzierżawców ceł i ze stratą własnych dochodów. Powoływał się na prośby bojarów, którzy ponieśli znaczne koszty, inwestując w destylarnie. Zasłaniał się też rzekomą troską o kondycję miejscowych chłopów rozpijanych tanim alkoholem przywożonym z Polski ${ }^{22}$. Argumentacja hospodara Mołdawii spotkała się z odpowiedzią

${ }_{17} \mathrm{Na}$ temat poselstw Boscampa-Lasopolskiego i Numana-beja pisali m.in.: J. Feldman, Na przetomie stosunków polsko-francuskich 1774-1787. Vergennes wobec Polski, Kraków 1935, s. 58-61; W. Konopczyński, Polska a Turcja 1683-1792, Warszawa 1936, s. 259-266; J. Reychman, Życie polskie, s. 47-49; J. Michalski, Dyplomacja polska, s. 595-597, 609-610; W. Filipczak, Sejm 1778 roku, Warszawa 2000, s. $20-23$.

${ }^{18}$ J. Reychman, Zatarg handlowy, s. 216-219. Dzieduszycki, przebywając w Stambule, nie miał oficjalnego statusu dyplomatycznego, oficjalnie był kierownikiem szkoły orientalnej. Por. J. Michalski, $D y$ plomacja polska, s. 597.

19 Du roi au comte de Monet, Varsovie, 22 IX 1779, Stanislas Poniatowski et Maurice Glayre: correspondence relative aux partages de la Pologne, wyd. E. Mottaz, Paris 1897, s. 168; J. Reychman, Zatarg handlowy, s. 216.

${ }^{20}$ Du roi au comte de Monet, s. 168-169. A. Stachiew był w latach 1776-1781 posłem rosyjskim w Stambule: B. Garskij, Stachijew, Aleksandr Stachijewicz, [w:] Russkij biograficzeskij stowar', t. XII, Moskwa 1909, s. 361; Instrukcje i reskrypty do ambasadorów rosyjskich $w$ Rzeczypospolitej $w$ latach 1772 1794, oprac. A. Danilczyk, J. Kordel, V. Anipiarkou, S. Łuczak, współpraca Z. Zielińska, Warszawa 2019, s. 126 (przyp. 119).

${ }^{21}$ J. Reychman, Zatarg handlowy, s. 216-217; V. Arapu, Componenta conflictuală, s. 86.

22 J. Reychman, Zatarg handlowy, s. 217; V. Arapu, Componenta conflictuală, s. 86. 
Dzieduszyckiego. Kwestionował w niej m.in. bezinteresowność hospodara kierującego się interesem bojarów, którzy założyli gorzelnie. Podawał też w wątpliwość rzekomą dbałość o trzeźwość chłopów, którzy teraz będą upijali się droższą wódką produkowaną w Mołdawii ${ }^{23}$. Arapu uważa, że w działaniach hospodara dominowały względy protekcjonistyczne ${ }^{24}$. Chodziło o ochronę interesów właścicieli gorzelni, których liczba w tym czasie szybko wzrastała. W roku 1776 w Mołdawii było 151 alembików (lokalna nazwa: velniță) produkujących miejscową wódkę (horilcă, rachiul ${ }^{25}$. Arapu przytacza wyliczenia, że w 1785 r. ich liczba, chodziło tu o produkcję rachiu ze zboża, doszła już do ok. $800^{26}$. Innego rodzaju motywację sugerował Reychman. Przytoczył on opinię przekazaną w wydanej w roku $1830 \mathrm{w}$ Paryżu broszurze Traite sur Les Princes de la Valachie et de Moldavie, której autorem był Marc-Philippe Zallony, osobisty lekarz Konstantyna Moruziego. Francuski medyk twierdził, że wchodziły w grę dość skomplikowane mechanizmy korupcyjne, które zapewniały hospodarowi wielkie dochody w wyniku łapówek branych od różnych grup interesów lub w efekcie konfiskaty przemycanego alkoholu ${ }^{27}$.

Dodatkowym czynnikiem utrudniającym wymianę towarów między oboma brzegami Dniestru było powtarzające się zagrożenie epidemiczne. Zanim jeszcze podjęte zostały działania mające przeciwdziałać epidemii dżumy, występującej przy granicy z Mołdawią na przełomie roku 1780 i 1781, w marcu 1780 o problemach w stosunkach handlowych z tym krajem pisał Józef Sosnowski. Hetman polny litewski (do rezygnacji z buławy w grudniu $1780 \mathrm{r}^{28}$ ) stwierdzał, że wojska koronne rozciągnięte kordonem nad granicami tatarską i ,wołoską", by chronić kraj przed rzekomą (zdaniem autora listu) zarazą, nie przepuszczają pochodzącej z Mołdawii soli. To zaś faworyzowało liwerantów z terenu monarchii habsburskiej, którzy mogli sprzedawać drożej i w większych ilościach sprowadzaną przez siebie sól. Sosnowski przewidywał, że sytuacja taka wywołała żądania władz tureckich i hospodara w sprawie przestrzegania zasad wolnego handlu ${ }^{29}$. Pominę omówienie skomplikowanej kwestii handlu solą w Rzeczypospolitej, gdyż została już opisana przez historyków (m.in.: Roman Rybarski, Jan A. Wilder,

${ }^{23}$ J. Reychman, Zatarg handlowy, s. 218. Arapu (Componenta conflictuală, s. 86) błędnie zidentyfikował autora polskiego memoriału, który przypisał Walerianowi Dzieduszyckiemu.

24 V. Arapu, Relatiile comerciale, s. 128.

${ }_{25}$ N. Dudnicenco, Băuturile alcoolice în Țara Moldovei (sec. XVI-XVIII), „Buletin Științific. Revistă de Etnografie, Științele Naturii și Muzeologie” 2014, vol. XXI (XXIV), s. 175-176; idem, Producerea și comercializarea băuturilor alcoolice in oraşele din Rzeczpospolita și Țara Moldovei (sec. XVI-XVII), „Studia Univeritatis Moldaviae" 2016, nr 4(94), s. 242-243.

${ }^{26}$ V. Arapu, Relatiile comerciale, s. 126.

27 J. Reychman, Zatarg handlowy, s. 223-224; idem, Życie polskie, s. 184-185.

${ }^{28}$ Z. Zielińska, Sosnowski Józef Sylwester, [w:] PSB, t. XL, s. 559-565. W 1781 r. Sosnowski został wojewodą połockim.

29 J. Sosnowski do Kończy, Szarogród, 2 III 1780 (ekscerpt), BCz, rkps 698, s. 863. 
Grażyna Bałtruszajtys, Radosław Gaziński) ${ }^{30}$. Warto jednak odnotować, że sól jest wymieniona przez Arapu jako drugi w kolejności, po towarach hodowlanych (chodziło zwłaszcza o bydło i konie), towar eksportu mołdawskiego do Polski ${ }^{31}$. W województwach południowo-wschodnich skutecznie konkurowała z solą sprowadzaną z zajętych przez Austrię kopalń małopolskich (Wieliczka, Bochnia, Sambor) ${ }^{32}$. Guldon wymienia sól nawet na pierwszym miejscu wśród towarów importowanych w latach 1784-1786 do Polski z Mołdawii ${ }^{33}$. Według danych z 1791 r. Mołdawia zajmowała szóste miejsce wśród krajów eksportujących do Polski sól ${ }^{34}$.

Problem zagrożenia epidemią dżumy, która pojawiła się na Podolu, Ukrainie i w Mołdawii, był poruszany w stambulskiej korespondencji władz polskich w listopadzie i grudniu roku $1780^{35}$. Na początku grudnia Pichelstein (oficjalnie tłumacz i kierownik szkoły orientalnej, faktycznie polski agent dyplomatyczny w Stambule ${ }^{36}$ ) w liście do Gabinetu królewskiego przedstawił swoją ocenę przyczyn, dla których działania w sprawie zniesienia zakazu sprzedaży polskiej gorzałki w Mołdawii uważał za rzecz bardzo trudną. Powoływał się na „urojoną wolność bojarów” oraz na przyjaciół hospodara mających wpływy w Porcie ${ }^{37}$. Jak pisał Pichelstein, Konstantyn Moruzi argumentował, że bojarzy otrzymali przywileje od sułtana i tylko Porta może powyższą decyzję cofnąć. Szef szkoły orientalnej widział tylko jeden skuteczny środek nacisku, mianowicie wstrzymanie eksportu polskiej mąki, gdyż wyłącznie tego obawiali się mołdawscy bojarzy. Pociągnąć to mogło jednak turecki zakaz importu innych polskich towarów. Sugero-

${ }^{30}$ R. Rybarski, Skarbowość Polski w dobie rozbiorów, Kraków 1937, s. 116-123; J.A. Wilder, Traktat handlowy, s. 156-164; G. Battruszajtys, Ktopoty z solq u schytku Rzeczypospolitej, [w:] Polska iświat. Ksiega poświęcona Bogustawowi Leśnodorskiemu, red. A Zahorski, Warszawa 1974, s. 225-243; R. Gaziński, Prusy a handel sola $w$ Rzeczypospolitej $w$ latach 1772-1795, Warszawa 2007, s. 175-307. Na temat poszukiwań soli w Rzeczypospolitej por. E. Danowska, Poszukiwania soli w Polsce w drugiej potowie XVIII wieku, „Kwartalnik Historii Nauki i Techniki” 2014, R. LIX, nr 3, s. 105-117.

31 V. Arapu, Relatiile comerciale, s. 106-107. Woły i konie stanowity tradycyjny towar eksportowy z terenu Mołdawii jeszcze przed rokiem 1772. Por. J. Motylewicz, Kupcy z krajów imperium tureckiego $w$ handlu naddniestrzańskim w potowie XVIII wieku, „Annales Academiae Paedagogicae Cracoviensis. Studia Historica” 2004, t. III, s. 384-385.

32 J.A. Wilder, Traktat handlowy, s. 154, 164.

33 Z. Guldon, Handel Polski, s. 58, 60. Por. R. Rybarski, Skarbowość Polski, s. 117.

${ }^{34}$ V. Arapu, Relatiile comerciale, s. 108.

35 A. Cieciszowski do S. Pichelsteina, Warszawa, 18 XI 1780 oraz 16 i 20 XII 1780, AGAD, ZP, sygn. 400, s. 67, 69, 71; Departament Interesów Cudzoziemskich do S. Pichelsteina, Warszawa, 9 XII 1780, AGAD, AKP, sygn. 83, s. 314-315.

${ }^{36}$ J. Reychman, Życie polskie, s. 67; idem, Ttumacze języków wschodnich w Polsce XVIII wieku, https://mlingua.pl/pol/czytelnia,,tlumacze_jezykow_wschodnich_w_polsce_xviii_wieku_jan_reychman_,a,501,p,8.html (dostęp: 24.03.2020); J. Michalski, Dyplomacja polska, s. 597.

${ }^{37}$ S. Pichelstein do A. Cieciszowskiego, Stambut, 1 XII 1780, AGAD, ZP, sygn. 400, s. 16-17. Wśród protektorów hospodara mołdawskiego wymieniał kiahja (lub kehaja) beja - według: N. Iorgi (Geschichte des Osmanischen, Bd. V, s. 29) był on tureckim odpowiednikiem ministra spraw wewnętrznych. 
wał, że po kilku miesiącach cierpliwego oczekiwania, proponowany środek przyniesie skutek i szlachta będzie mogła czerpać korzyści zarówno z eksportu mąki, jak i wywozu wódki ${ }^{38}$. W tym okresie Mołdawia, zwłaszcza w latach nieurodzaju spowodowanego suszą (tak było np. w 1782 r.), importowała z Polski znaczne ilości zboża ${ }^{39}$.

W styczniu 1781 r. w korespondencji Departamentu Interesów Cudzoziemskich dziękowano Pichelsteinowi za starania o przywrócenie eksportu wódek z terenu Polski i sugestie co do wstrzymania wywozu mąki. Jednak zwracano mu uwagę na konieczność dokładniejszego szyfrowania wysyłanej korespondencji. Ponadto wyrażano obawę, że Austriacy mogli wykorzystać pozyskane z niej informacje do wejścia na rynek mołdawski z własną mąką ${ }^{40}$. W tym kontekście odniesiono się również do propozycji formalnego zakazu wywożenia mąki z Korony, co miało być formą presji na Konstantyna Moruziego, by cofnął restrykcje w sprawie importu polskiej wódki. Stwierdzono, że takie działania wymagałyby decyzji sejmu ${ }^{41}$. Niechęć do blokowania eksportu zboża do Mołdawii wynikała nie tylko z powodów prawno-ustrojowych. W grę wchodziły gospodarcze interesy szlachty z Podola i Ukrainy. W latach urodzaju ceny zboża były bardzo niskie (tak było np. w roku 1779 i 1782), a towarzyszył temu także problem z jego zbytem ${ }^{42}$.

W odpowiedzi na grudniowe sugestie Pichelsteina, Departament w styczniu $1781 \mathrm{r}$. polecił mu zachęcanie opozycyjnych bojarów mołdawskich do nacisków w tej kwestii na Portę. Jeśli to nie wystarczy, uznano za niezbędne wystosowanie w tej sprawie formalnych pretensji. Anonsowano także, niezrealizowany później, powrót nad Bosfor Dzieduszyckiego, który zakończył już działania mające uśmierzyć dżumę na Ukrainie i miał ruszyć w podróż, kiedy powróci do zdrowia ${ }^{43}$. W czasie pełnienia swojej misji złamał obojczyk, co nie przeszkodziło mu w dalszym wypełnianiu obowiązków w zakresie walki z epidemią ${ }^{44}$. Dzieduszycki jednak do Stambułu nie wrócił, gdyż w 1781 r. został sekretarzem Departamentu Interesów Cudzoziemskich, zastępując na tym

38 S. Pichelstein do A. Cieciszowskiego, Stambut, 1 XII 1780, AGAD, ZP, sygn. 400, s. 17-18.

39 V. Arapu, Relatiile comerciale, s. 116-117, 119. Por. też Z. Guldon, Handel Polski, s. 58-60.

${ }^{40}$ Departament Interesów Cudzoziemskich do S. Pichelsteina, Warszawa, 20 I 1781, AGAD, AKP, sygn. 83 , s. 317 .

41 Ibidem.

${ }^{42}$ J. Reychman, Zatarg handlowy, s. 226; D. Rolnik, Leonarda Marcina Świeykowskiego (1721-1793) ostatniego wojewody podolskiego życie codzienne i publiczne oraz jego myśli o Rzeczypospolitej, Katowice 2016, s. 330-331.

43 Departament Interesów Cudzoziemskich do S. Pichelsteina, Warszawa, 20 I 1781, AGAD, AKP, sygn. 83, s. 317-318. W tym czasie dotarła do Pichelsteina wiadomość, jakoby na placówkę stambulską miał przybyć Zamoyski (brak dokładniejszych określeń): S. Pichelstein do A. Cieciszowskiego, Stambuł, 16 I 1781, AGAD, ZP, sygn. 399, s. 24. Pojawiła się w tym czasie także kandydatura Augusta Kickiego: J. Reychman, Życie polskie, s. 88; J. Michalski, Dyplomacja polska, s. 597.

44 T. Srogosz, Między wojna a modernizacja, s. 231-232. 
stanowisku Michała Mniszcha, który w maju tego samego roku otrzymał urząd marszałka nadwornego litewskiego ${ }^{45}$.

W ostatniej dekadzie marca 1781 r. przebywający w Jaryszowie pod Mohylowem (na Podolu) Dzieduszycki informował Gabinet królewski o sytuacji na pograniczu Podola i Mołdawii. Główny problem na tym terenie (województwa bracławskie i podolskie oraz Mołdawia) stanowiła plaga szarańczy, która pojawiła się już po likwidacji zagrożenia związanego z epidemią dżumy ${ }^{46}$. Dzieduszycki pisał do Cieciszowskiego, że hospodar trzy tygodnie wcześniej zakazał w całej Mołdawii wykorzystywania zboża do produkcji gorzałki. Zalecił też sprowadzanie go z Polski. Dzieduszycki uważał, że groziło to ogołoceniem Ukrainy i Podola z chleba, zwłaszcza wobec nieurodzaju w 1780 r. i szkód, którymi groziła pojawiająca się szarańcza. Proponował więc wprowadzić zakaz wywozu zboża. Wysłał też raport do królewskiego bratanka, ks. Stanisława Poniatowskiego, który pełnił w latach 1780-1782 funkcję marszałka Rady Nieustającej ${ }^{47}$.

W liście Dzieduszyckiego sprawa wstrzymania eksportu zboża pojawiła się bez odniesienia do zakazu importu polskiej wódki do Mołdawii. Nie sądzę jednak, aby kwestie te nie miały ze sobą związku. Może o tym świadczyć stanowisko, jakie zajęła szlachta graniczącego z hospodarstwem województwa bracławskiego. W lipcu 1781 r. kasztelan bracławski Marcin Grocholski informował króla o memoriale obywateli tegoż województwa skierowanym do monarchy. Powołano się w nim na klęskę szarańczy na Ukrainie i domagano wprowadzania zakazu wywozu zboża, co miało uchronić kraj przed głodem. Sugerowano także, w odpowiedzi na zakaz importu do Mołdawii wódek z Bracławszczyzny, by zabronić sprowadzania do kraju win mołdawskich („wołoskich”) ${ }^{48}$. Wino stanowiło ważny towar mołdawskiego eksportu do Polski. Po ustąpieniu przez Turcję Habsburgom mołdawskiej Bukowiny, w konwencji z 7 maja 1775 r. ${ }^{49}$, władze austriackie doprowadziły do ograniczenia eksportu win z regionu Cotnari (na północny zachód od Jass), wysoko cenionych nie tylko przez Polaków. W efekcie centrum produkcji i handlu winem przeniosło się do Odobeşti ${ }^{50}$ (w południowo zachodniej Mołdawii).

Zanim dotarły do Stambułu zalecenia Warszawy ze stycznia 1781 r., Pichelstein sugerował - w wypadku wysłania nowego posła do Turcji - skierowanie do wezyra li-

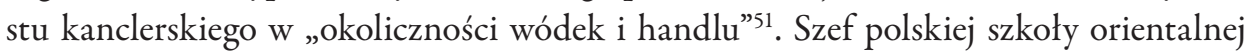

${ }^{45}$ Z. Anusik, Organizacja ifunkcjonowanie, s. 54-55. Por. też J. Reychman, Życie polskie, s. 88.

46 A. Dzieduszycki do A. Cieciszowskiego, Jaryszów, 23 III 1781, AGAD, ZP, sygn. 399, s. 3. Epidemia dżumy została opanowana już w lutym 1781. Por. T. Srogosz, Między wojna a modernizacja, s. 234.

47 A. Dzieduszycki do A. Cieciszowskiego, Jaryszów, 23 III 1781, AGAD, ZP, sygn. 399, s. 3-4. Poniatowski został wybrany na marszałka Rady w czasie sejmu na sesji 12 X 1780 r. Por. W. Filipczak, Życie sejmikowe prowincji wielkopolskiej w latach 1780-1786, Łódź 2012, s. 61.

48 M. Grocholski do króla, 26 VII 1781, BCz, rkps 663, s. 320-321.

${ }^{4}$ V. Ciobanu, Relațiile politice, s. 128. Por. też J. Demel, Historia Rumunii, wyd. 2, Wrocław 1986, s. 229.

50 V. Arapu, Relatiile comerciale, s. 111-112.

51 S. Pichelstein do A. Cieciszowskiego, Stambuł, 16 I 1781, AGAD, ZP, sygn. 399, s. 24. 
z pewnym opóźnieniem podjął starania, aby wykonać wspomniane wcześniej zalecenia Departamentu Interesów Cudzoziemskich. W końcu marca 1781 r. tłumaczył, że czekał na lepszą koniunkturę, gdyż dopóki żył poprzedni wielki wezyr, którego hospodar był „kreaturą”, nie mógł liczyć na sukces. Kiedy Silahdar Seyyid Mehmed Pasza zmarł w lutym tego samego roku, Pichelstein przystąpił do działania ${ }^{52}$. Polski agent twierdził, że pozyskał „wszystkich oficjalistów Porty”. Po przybyciu nowego wielkiego wezyra (był nim Izzet Mehmed Pasza) przedstawił mu swoje skargi i „remonstracyję"53. Pichelstein liczył na to, że „dygnitarze Porty radziby co kwartał inszego mieć książęcia [hospodara - W.F.], bo najmniej pięćset kies między nich rozruca" ${ }^{54}$. Relację polskiego dragomana w Stambule potwierdza Ciobanu, który na marzec 1781 r. datuje początki zabiegów Pichelsteina zmierzających do usunięcia z tronu w Jassach Konstantyna Moruziego 55 . W końcu kwietnia szef szkoły orientalnej spodziewał się, jak wynika z listu do Gabinetu, że Porta wyda „dokładny ferman” hospodarowi, ,aby takiemi nowemi zwyczajami” nie zakłócał stosunków polsko-tureckich ${ }^{56}$. Ferman nosił datę 11 maja 1781 r. Stwierdzano w nim, że przeszkody w handlu z obywatelami polskimi czynione przez hospodara i bojarów nie były zgodne z wolą sułtana. W dokumencie przypomniano rozkazy wydane w roku 1760 władcy mołdawskiemu w odpowiedzi na poselstwo Rzeczypospolitej odprawione przez kuchmistrza litewskiego Józefa Antoniego Podoskiego ${ }^{57}$. W fermanie nakazywano hospodarowi postępować zgodnie z ustalonymi wówczas zasadami. Powołano się też na memoriał, który przedstawił w tej sprawie, w imieniu króla i Rzeczypospolitej, tłumacz (dragoman) polski Pichelstein. Konstantyn Moruzi miał postępować z kupcami i obywatelami polskimi według reguł stosowanych przez jego poprzedników, bez naruszania zasad sąsiedztwa i przyjaźni ${ }^{58}$.

W końcu maja 1781 r. Pichelstein pisał, że po wydaniu sułtańskiego fermanu rezydenci Konstantyna Moruziego „różnemi mnie nareszcie ujmowali sposobami”, aby nie szkodził resztkom względów Porty dla hospodara. Bezpodstawnie, jak się później okaże, zakładał, że „będziemy mieli wolność przechodu wódek naszych” ${ }^{59}$. Dwa

52 S. Pichelstein do A. Cieciszowskiego, Stambut, 31 III 1781, AGAD, ZP, sygn. 399, s. 84. Na temat wielkiego wezyra Silahdara Mehmeda Paszy por. K. Şakul, Hattat Ismail Zihni Pasha: Life and Death of an Ottoman Statesman and an Inventor, „Osmanli Arastirmalari / The Journal of Ottoman Studies” 2014, issue 44, s. 70 .

53 S. Pichelstein do A. Cieciszowskiego, Stambul, 31 III 1781, AGAD, ZP, sygn. 399, s. 84. Por. V. Ciobanu, Relațiile politice, s. 144.

54 S. Pichelstein do A. Cieciszowskiego, Stambuł, 31 III 1781, AGAD, ZP, sygn. 399, s. 84.

55 V. Ciobanu, Relațiile politice, s. 144.

56 S. Pichelstein do A. Cieciszowskiego, Stambut, 30 IV 1781, AGAD, ZP, sygn. 399, s. 113.

57 Tłumaczenie fermanu z 11 V 1781, AGAD, ZP, sygn. 399, s. 131-132; J.A. Gierowski, Dyplomacja polska doby saskiej (1699-1763), [w:] Historia dyplomacji polskiej, s. 386.

58 Tłumaczenie fermanu z 11 V 1781, AGAD, ZP, sygn. 399, s. 132-134.

59 S. Pichelstein do A. Cieciszowskiego, Stambuł, 26 V 1781, AGAD, ZP, sygn. 399, s. 135-136. 
tygodnie później Stanisław August w liście do Augustyna Debolego, posła Rzeczypospolitej w Rosji, pozytywnie oceniał starania podejmowane przez polskiego dragomana w Stambule w celu uzyskania fermanu nakazującego zniesienie ograniczeń w sprawie sprzedaży polskich trunków w Mołdawii ${ }^{60}$. W korespondencji pisanej rok później wspominał o wsparciu, którego udzielił w tej sprawie rosyjski poseł Stachiew ${ }^{61}$.

W czerwcu 1781 r. Departament Interesów Cudzoziemskich informował Pichelsteina, że Stambuł polecił hospodarowi, by „handlu naszego nowościami nie mieszał”. Ferman był natychmiast przekazany sztafetą do Kamieńca Podolskiego. Komendant twierdzy - gen. Jan Witte miał wysłać do Jass, z listem do hospodara napisanym w imieniu króla i Rady Nieustającej, Piotra Giulianiego służącego w Kamieńcu w charakterze tłumacza ${ }^{62}$. List nosił datę 17 czerwca $1781 \mathrm{r}$. Został przekazany za pośrednictwem Giulianiego i porucznika Kuczyńskiego ${ }^{63}$. Początkowy entuzjazm szybko minął, gdyż miesiąc później skonstatowano, że ferman Porty przesłany Moruziemu nie przyniósł żadnego skutku. Warszawa polecała Pichelsteinowi wyrazić zadowolenie polskich władz z powodu przyjacielskiej deklaracji Porty i zdziwienie nieposłuszeństwem hospodara ${ }^{64}$. W końcu lipca szef szkoły orientalnej stwierdzał, że kurier od Moruziego, który przybył do Stambułu wyjaśniał, dlaczego hospodar nie odpisał Radzie Nieustającej. Tłumaczył się, że Rada wydała mu się „nową jakąś władzą dawnym krajowym ustawom przeciwną, której Porta i on znać nie powinni”. Planował nawet odpisać hetmanowi wielkiemu koronnemu Franciszkowi Ksaweremu Branickiemu (jednemu z liderów opozycji magnackiej), ale ostatecznie napisał do gen. Witte ${ }^{65}$.

Z korespondencji Departamentu z początku sierpnia 1781 r. wynika, że przyczyną nieskuteczności fermanu był brak w tekście wzmianki o wódce. Reis-efendi (turecki odpowiednik ministra spraw zagranicznych, choć o mniejszych kompetencjach ${ }^{66}$ ) miał

${ }^{60}$ Król do A. Debolego, 11 VI 1781, Korespondencja polityczna Stanistawa Augusta. Augustyn Deboli 1781, oprac. E. Zielińska, A. Danilczyk, Warszawa 2015, s. 240.

${ }^{61}$ Król do A. Debolego, 8 VII 1782 r., Korespondencja polityczna Stanistawa Augusta. Augustyn Deboli 1782, oprac. E. Zielińska, A. Danilczyk, Warszawa 2017, s 169.

${ }^{62}$ Departament Interesów Cudzoziemskich do S. Pichelsteina, Warszawa, 20 VI 1781, AGAD, AKP, sygn. 83, s. 329; Giuliani został skierowany ze Stambułu do Kamieńca Podolskiego w 1779: J. Reychman, Życie polskie, s. 87. Por. też idem, Giuliani Piotr, [w:] PSB, t. VIII, s. 13; idem, Ttumacze języków wschodnich w Polsce.

${ }^{63}$ J. Witte do A. Dzieduszyckiego, Kamieniec Podolski, 30 VI 1781 i kopia listu pisanego po łacinie do hospodara mołdawskiego, AGAD, AKP, sygn. 123, s. 350-353.

${ }^{64}$ Departament Interesów Cudzoziemskich do S. Pichelsteina, Warszawa, 18 VII 1781, AGAD, AKP, sygn. 83, s. 333-334.

${ }^{65}$ S. Pichelstein do A. Cieciszowskiego, Stambul, 26 VII 1781, AGAD, ZP, sygn. 399, s. 168; J. Reychman, Zatarg handlowy, s. 220.

${ }^{66} \mathrm{~J}$. Mazanec, The Ottoman Empire at the beginning of Tanzimat Reforms, „Prague Papers on the History of International Relations" 2016, No. 2, s. 28. Związany ze szkołą języków orientalnych Józef Mikosza (Obserwacye polityczne państwa tureckiego [...], cz. 1, Warszawa 1787, s. 76-77) widział 
tłumaczyć, „iż to się z haryngą ich fermanów nie zgadza”67. Latem tego samego roku o sprawie eksportu gorzałki z Moruzim rozmawiał nawet ks. Stanisław Poniatowski, ówczesny marszałek Rady Nieustającej ${ }^{68}$.

Pod koniec września 1781 r. sprawa wymiany handlowej z Mołdawią i Turcją stała się znowu tematem korespondencji Departamentu z Pichelsteinem. Powoływano się na gotowość Polaków do sprzedaży Turcji potrzebnych jej towarów, co jednak torpedowała polityka księcia mołdawskiego (tak zwykle określano hospodarów w korespondencji). Przytaczano opinie obywateli województw podolskiego, bracławskiego i kijowskiego, którzy domagali się wyjaśnienia, na jakiej podstawie hospodarowie nie wykonująfermanów Porty. Zalecano więc, aby Pichelstein skierował pytanie w tej sprawie do reis-efendiego ${ }^{69}$. W październiku $1781 \mathrm{r}$. Dzieduszycki informował polskiego przedstawiciela w Stambule o podróży króla na Ukrainę, która miała związek z przejazdem przez Rzeczpospolitą (w drodze do Wiednia) wielkiego księcia Pawła z małżonką ${ }^{70}$. Po wizycie u marszałka nadwornego litewskiego Mniszcha w Wiśniowcu monarcha miał udać się na Podole i tam zorientować się w sytuacji związanej z konfliktem handlowym. Spotkanie z miejscowymi obywatelami powinno stać się okazją do obmyślenia środków zaradczych. Już wówczas pojawiła się idea wysłania przez obywateli „województw pogranicznych" listu do księcia mołdawskiego w sprawie usunięcia przeszkód w prowadzeniu handlu. Gen. Witte zalecono domagać się od paszy chocimskiego, aby poinformował Portę o skargach na nieposłuszeństwo hospodara. Pichelsteinowi nakazano zaś interwencję w tej sprawie u reis-efendiego ${ }^{71}$.

Nawet nowy ferman turecki sułtana Abdülhamida I z 10 grudnia 1781 r., już wyraźnie wymieniający wódkę, nie zmienił postępowania Konstantyna Moruziego ${ }^{72}$. Hospodar jednak, aby móc realizować dostawy zboża do Stambułu, wprowadził ułatwienia dla importu tego towaru z Polski. W tym samym celu w styczniu 1782 r. zakazano

w reis-efendim odpowiednika kanclerza. Na temat Mikoszy por. E. Siemieniec-Gołaś, Józef Mikosza i jego "Obserwacje polityczne państwa tureckiego”, „Colloquia Orientalia Bialostocensia. Literatura/Historia” 2017, nr 29, s. 53-56.

${ }^{67}$ Departament Interesów Cudzoziemskich do S. Pichelsteina, Warszawa, 1 VIII 1781, AGAD, AKP, sygn. 83, s. 336. Reis-efendi podobno obiecywał napisać osobny list do hospodara.

${ }^{68}$ J. Reychman, Zatarg handlowy, s. 220. Brak wzmianki na ten temat w: J. Michalski, Poniatowski Stanistaw, [w:] PSB, t. XXVII, s. 483-484. Należy jednak zauważyć, że przez pewien czas Poniatowskiego nie było w Warszawie, np. na sesji Rady z 10 VIII 1781 r. zastępował go generał artylerii koronnej Alojzy Brühl. Por. Protokół Rady Nieustającej z 10 VIII 1781, AGAD, tzw. Metryka Litewska, dz. VII, sygn. 39, k. 33v.

69 A. Dzieduszycki do S. Pichelsteina, Warszawa, 26 IX 1781, AGAD, AKP, sygn. 83, s. 343-345.

70 A. Dzieduszycki do S. Pichelsteina, Warszawa, 10 X 1781, AGAD, AKP, sygn. 83, s. 347; W. Filipczak, Stronnictwo regalistyczne w województwie kijowskim 1780-1782, „Przegląd Nauk Historycznych" 2009, R. VIII, nr 1, s. 90.

${ }^{71}$ A. Dzieduszycki do S. Pichelsteina, Warszawa, 10 X 1781, AGAD, AKP, sygn. 83, s. 347-348.

${ }^{72}$ J. Reychman, Zatarg handlowy, s. 220. 
używania pszenicy do wyrobu gorzałki (horilcă) ${ }^{73}$. W lutym tego samego roku grudniowy ferman został przekazany gen. Witte, do Kamieńca. Miał on wysłać do Jass Giulianiego z pytaniem, czy hospodar wypełni wspomniany rozkaz sułtana. Jednocześnie informowano Pichelsteina, że na polecenie króla podkomorzy latyczowski Kazimierz Józef Lipiński napisze do Moruziego list w imieniu obywateli podolskich ${ }^{74}$. W końcu lutego i na początku marca 1782 r. nadzieje w Warszawie wzbudziła zmiana na tronie wołoskim. W Bukareszcie miejsce „oświeconego despoty”75 Aleksandra Ipsilanti zajął Mikołaj Caragea (Caradja), dotychczasowy dragoman w tureckiej stolicy. Jednocześnie odnotowano, że nie nadeszła jeszcze odpowiedź na skargi w sprawie eksportu polskiej wódki. Żałowano też, iż nowy władca Wołoszczyzny nie zasiadł na tronie mołdawskim ${ }^{76}$.

Wkrótce doszło do oczekiwanej przez władze polskie zmiany hospodara w Jassach. Nie była niespodzianką, gdyż dyplomaci pruscy już przeszło miesiąc wcześniej wiedzieli, że może niebawem nastąpić ${ }^{77}$. W dniu 8 czerwca 1782 r. miejsce Konstantyna Moruziego zajął Aleksander Mavrocordat I (zwany Deli bejem, czyli „szalonym księciem" ${ }^{78}$. Miesiąc później król w liście do Debolego uznawał usunięcie hospodara za niespodziewane („la déposition inattendue du hospodar de Moldavie”). Stanisław August podkreślał wsparcie, jakiego polskim staraniom w sprawie uwolnienia sprzedaży polskich gorzałek udzielali kolejni ambasadorowie Rosji w Stambule: Stachiew i Jakow Bułhakow $^{79}$. Nieskuteczność fermanu z maja 1781 r. król tłumaczył skrupułami muzułmańskich teologów kwestionujących legalność spożywania takich trunków przez tureckich poddanych. Monarcha liczył, że dzięki zmianie na tronie polskie oczekiwania w tej sprawie zostaną spełnione, a przynajmniej, że jej skutki wkrótce się ujawnią ${ }^{80}$.

${ }^{73}$ A. Gonța, Începutul industriei alcoolului în Moldova feudală, „Anuarul Institutului de Istorie și Arheologie A. D. Xenopol” 1971, t. VIII, s. 149; V. Arapu, Relatiile comerciale, s. 128-129. Podobne, a nawet dalej idące zakazy były ponawiane w okresie późniejszym.

${ }^{74}$ A. Dzieduszycki do S. Pichelsteina, Warszawa, 9 II 1782, AGAD, AKP, sygn. 83, s. 369.

${ }^{75}$ K. Hitchins, The Romanians, 1774-1866, Oxford 1996, s. 21-22. Według: S. Pichelstein do A. Cieciszowskiego, Stambul, 8 II 1782 (AGAD, ZP, sygn. 398, s. 18-19) Aleksander Ipsilanti miał zrezygnować z tronu pod wpływem kryzysu psychicznego wywołanego wyjazdem (bez wiedzy ojca) jego dwóch synów do Wiednia. Por. też V. Mischevca, Legăturile domnului fanariot Alexandru Ypsilanti cu Imperiul Habsburgic in ultimul sfert al secolului al XVIII-lea, „Revista de Istorie a Moldovei” 2015, nr 4(104), s. 69.

76 A. Dzieduszycki do S. Pichelsteina, Warszawa, 27 II i 9 III 1782, AGAD, AKP, sygn. 83, s. 372-373.

77 Acte şi fragmente cu privire la istoria Romînilor [...], wyd. N. Iorga, t. II (Extracte din corespondența ambasadorilor prusienǐ la Constantinopol şi Petersburg cu privire la Țerile Romîne), Bucureştǐ 1896, s. 160 (von Gaffron do Fryderyka II, Konstantynopol - odebrany 7 V 1782).

78 Acte şi fragmente, t. II, s. 160 (von Gaffron do Fryderyka II, Konstantynopol, 10 VI 1782); V. Ciobanu, Relațiile politice, s. 144.

79 Król do A. Debolego, 8 VII 1782, Korespondencja polityczna... 1782, s. 169. Buthakow zastąpił Stachiewa na funkcji ambasadora w Turcji w 1781 r. Por. P.M. Majkow, Butgakow, Jakow Iwanowicz, [w:] Russkij biograficzeskij stowar', t. III, Moskwa 1908, s. 469; Instrukcje i reskrypty, s. 240 (przyp. 248).

${ }^{80}$ Król do A. Debolego, 8 VII 1782, Korespondencja polityczna... 1782, s. 169. 
Sprawa ta znalazła też odbicie w korespondencji krajowej Stanisława Augusta. W lipcu król pisał na ten temat do kasztelana bracławskiego M. Grocholskiego, wojewody połockiego J. Sosnowskiego i dwukrotnie do K.J. Lipińskiego, podkomorzego latyczowskiego (później podolskiego). Stanisław August podkreślał wpływ działań dworu w sprawie uchylenia zakazu importu polskich wódek do Mołdawii na decyzję o zmianie na tronie hospodarskim. Monarcha pisał, że Turcy zalecili nowemu władcy, aby nie dawał Polakom okazji do uskarżania się ${ }^{81}$.

Rodzi się pytanie, czy opinie króla można uznać za wiarygodne. Według Aleksandra Stourdzy upadek Moruziego miał związek z działaniami rosyjskiego ambasadora w Turcji Bułhakowa ${ }^{82}$. Skarżył się on na postępowanie hospodara w stosunku do konsula w Jassach Sergieja Łaskariowa, choć zdaniem rumuńskiego badacza, sprawa ta została wykorzystana przez Portę jako pretekst ${ }^{83}$. Amerykański historyk Keith Hitchins pisał, że Aleksander Mavrocordat kupił w 1782 r. prawo do tronu mołdawskiego za sumę miliona piastrów ${ }^{84}$. Ciobanu uważał, że po zmianie na urzędzie wielkiego wezyra (w lutym 1781 r. Silahdara Seyyida Mehmeda paszę zastąpił Izzet Mehmed pasza), kiedy Moruzi stracił protektora w Stambule, znaczenie działań Pichelsteina nie było nieistotne ${ }^{85}$. Rumuński historyk uzasadniał swoje stanowisko oficjalnymi wypowiedziami władz tureckich i reakcjami polskimi na wieść o zmianie hospodara, co trudno uznać za argument rozstrzygający. O zasługach Pichelsteina w tej sprawie miało świadczyć m.in. stanowisko szlachty podolskiej oczekującej, że sejm nobilituje szefa szkoły orientalnej ${ }^{86}$. Jednak punkt w tej sprawie nie znalazł się w instrukcji poselskiej uchwalonej przez sejmik w Kamieńcu Podolskim ${ }^{87}$. W rzeczywistości inicjatywa wyszła zaś od samego Pichelsteina. W liście z 26 sierpnia 1782 r. (tydzień po sejmikach przedsejmowych) pisał on do Cieciszowskiego z prośbą, by szef Gabinetu rekomendował go posłom podolskim

${ }^{81}$ Król do M. Grocholskiego, 25 VII 1782 (minuta listu), BCz, rkps 663, s. 403-405; król do J. Sosnowskiego, 24 VII 1782 (minuta listu), BCz, rkps 688, s. 255; król do K. J. Lipińskiego, 25 VII 1782 i 8 VIII 1782 (minuty listów), BCz rkps 671, s. 318-319, 327.

82 A. Stourdza, L'Europe Orientale, s. 243.

${ }^{83}$ Ibidem. Łaskariow (Laşcariov) był konsulem rosyjskim w Bukareszcie i w Jassach od lutego $1780 \mathrm{r}$. Por. M. Stroia, Racordarea societății românești la modele europene: instalarea consulatelor străine în Moldova și Țara Românească, „Revista Institului Diplomatic Român” 2007, a. II, nr 2(4), semestrul 2, s. 405.

${ }^{84}$ K. Hitchins, The Romanians, s. 17.

85 V. Ciobanu, Relațiile politice, s. 144-145: „Satisfacția pe care au manifestat-o autoritățile poloneze la vestea inlocuirii lui Constantin Moruzi cu Alexandru Mavrocordat I Deli-bei, la 8 iunie 1782, felicitările pe care le-a transmis regele lui de Pichelstein, precum și hotătirea noblimii podoliene de a cere regelui și Seimului înnobilarea lui, permit să se tragă concluzia că contribuția acestuia la inlăturarea domnului nu a fost neglijabilă".

${ }^{86}$ Ibidem, s. 144.

${ }^{87}$ Ekscerpt instrukcji poselskiej województwa podolskiego z 1782 r., AGAD, ZP, sygn. 126, k. 144145. W punkcie nr 17 (k. 144v) wśród osób, o których nobilitację posłowie podolscy mieli się starać, Pichelstein nie został wymieniony. 
i bracławskim. Mieli oni prosić króla i sejm o przyznanie Pichelsteinowi indygenatu ${ }^{88}$. Burzliwe obrady parlamentu jesienią 1782 r. nie dawały żadnych szans na realizację tego życzenia ${ }^{89}$.

Przekonanie władz polskich o znaczeniu ich zabiegów w Stambule znajduje potwierdzenie w informacjach samego Pichelsteina, choć trzeba zastrzec, że był on osobiście zainteresowany w podkreślaniu własnych zasług. Według relacji z września $1782 \mathrm{r}$. zabiegi polskiego agenta w Stambule wsparł ambasador rosyjski w Turcji Bułhakow ${ }^{90}$. Jednak dalsze losy sporu wokół sprzedaży polskich wódek do Mołdawii nie potwierdzają tezy o zasadniczej roli polskich działań w obaleniu Konstantyna Moruziego.

Wróćmy do krajowej korespondencji Stanisława Augusta z lipca 1782 r. W liście do Sosnowskiego monarcha pisał o wyprawie starosty romanowskiego Józefa Lubomirskiego do Jass, skąd magnat w towarzystwie Konstantyna Moruziego miał udać się do Stambułu. Stanisław August obawiał się, że eks-hospodar będzie w Wysokiej Porcie szkodził polskim interesom ${ }^{91}$. Król niepokoił się także, że Moruzi, współdziałając z Lubomirskim, może spowodować, iż zakaz eksportu polskich trunków do Mołdawii zostanie utrzymany. Stanisław August prosił Sosnowskiego, by nakłonił swego zięcia ${ }^{92}$ do rezygnacji z podróży lub przynajmniej, by Lubomirski w tureckiej stolicy współdziałał z Pichelsteinem ${ }^{93}$. W odpowiedzi z 8 sierpnia 1782 r. Sosnowski wyjaśnił, że jego zięć powrócił z Jass już trzy tygodnie temu, zaś na potwierdzenie przesłał Stanisławowi Badeniemu diariusz jego podróży do Mołdawii ${ }^{94}$. Informacja Sosnowskiego znajduje potwierdzenie w liście gen. Witte z początku sierpnia tego samego roku. Komendant twierdzy kamienieckiej pisał, że Lubomirski powrócił już z Jass. Konstantyn Moruzi też już opuścił stolicę Mołdawii. Witte powoływał się na pogłoskę - jak się okaże fałszywą - że ma on zostać hospodarem Wołoszczyzny. Stwierdzał też, że sprzedaż wódek odbywa się, ale w tajemnicy. Zakładał, że ten stan będzie trwać do przyjazdu nowego hospodara ${ }^{95}$.

Innych kwestii dotyczyły listy monarchy do Grocholskiego i do Lipińskiego, czołowych postaci stronnictwa regalistycznego w województwach bracławskim i podolskim $^{96}$. Monarcha powołał się na rady udzielone przez nowego hospodara. Aleksander

${ }^{88}$ S. Pichelstein do A. Cieciszowskiego, Stambut, 26 VIII 1782, AGAD, ZP, sygn. 398, s. 80. Pichelstein od dłuższego czasu oczekiwał na indygenat. Por. J. Reychman, Życie polskie, s. 85.

89 W. Filipczak, Życie sejmikowe, s. 93-100.

90 S. Pichelstein do A. Cieciszowskiego, Stambut, 9 IX 1782, AGAD, ZP, sygn. 398, s. 87.

91 Król do J. Sosnowskiego, 24 VII 1782 (minuta listu), BCz, rkps 688, s. 255.

92 J. Lubomirski był mężem Ludwiki z Sosnowskich: J. Kowecki, Lubomirski Józef, [w:] PSB, t. XVIII, s. $27-28$.

93 Król do J. Sosnowskiego, 24 VII 1782 (minuta listu), BCz, rkps 688, s. 256-258.

${ }^{4}$ J. Sosnowski do S. Badeniego i do króla, Sosnowica, 8 VIII 1782, BCz, rkps 688, s. 261-264.

95 J. Witte do A. Cieciszowskiego, Kamieniec Podolski, 3 VIII 1782, BCz, rkps 694, s. 353-356.

96 W. Filipczak, Relacje między liderami stronnictwa regalistycznego na terenie Ukrainy w latach 17831784, [w:] Historia na źródtach oparta. Studia ofiarowane Profesorowi Tadeuszowi Srogoszowi w 65. rocznicę urodzin, red. A. Stroynowski, Częstochowa 2017, s. 667-668. 
Mavrocordat I sugerował napisanie do niego listów przez „znaczne osoby” spośród obywateli podolskich i bracławskich. Mieli się oni skarżyć na niedotrzymanie traktatów sąsiedzkich w wyniku zakazu wwozu do Mołdawii polskich destylatów. Król przesyłał też formularz listu do nowego hospodara ${ }^{97}$. Lipiński wykonał zalecenie monarchy, a list przekazał Giulianiemu. Podkomorzy latyczowski zobligował też gen. Witte, aby wysłał Giulianiego do Jass ${ }^{98}$. Komendant twierdzy wyprawił tłumacza kamienieckiego dopiero w połowie sierpnia, gdyż wiedziano, że nowy książę mołdawski jeszcze się nie pojawił w swojej stolicy. Później zamierzano przesłać instrukcję dla Giulianiego i pismo Grocholskiego do hospodara ${ }^{99}$. Sprawa nie jest jasna, gdyż kasztelan bracławski już 4 sierpnia 1782 r. informował króla, że wysłał nowemu władcy nie tylko list, ale także zwyczajowy prezent z okazji inauguracji rządów ${ }^{100}$. Z późniejszej korespondencji Grocholskiego wynika, że ok. 20 sierpnia tego samego roku Aleksander Mavrocordat nie przybył jeszcze do Mołdawii, a zapewne przebywał wciąż w Stambule ${ }^{101}$. W początkach września Stanisław August zastanawiał się, czy nowy hospodar po przybyciu do Jass zrealizuje polskie żądania ${ }^{102}$. W grudniu 1782 r. Lipiński pisał, że otrzymał odpowiedź na swój list w sprawie przywrócenia przywozu polskich gorzałek, jednak władca Mołdawii wciąż wstrzymywał się z ostateczną deklaracją. Brak pozytywnej decyzji wynikał z interesów mołdawskich bojarów. Podkomorzy podolski informował Cieciszowskiego, że ponowił żądanie w imieniu szlachty podolskiej. Było to zgodne z sugestiami Giulianiego, którego w Jassach przestrzegano, by nie zaprzestawać składania skarg ${ }^{103}$. Lipiński pisał też, że chęć wsparcia polskich wysiłków zgłaszał rosyjski konsul w Jassach Łaskariow, który deklarował również gotowość ochrony przed nadużyciami polskich kupców, podobnie jak to robił w odniesieniu do rosyjskich. Oczekiwał jednak na polecenie w tej sprawie od dworu petersburskiego ${ }^{104}$. Odpowiedź na list otrzymał też Grocholski, choć nie wiadomo, kiedy to dokładnie nastąpiło. W maju 1783 r. kasztelan bracławski pisał do króla, że hospodar „w dawniejszym responsie” czynił mu nadzieję na ustępstwa, po naradzeniu się z mołdawskimi bojarami. Grocholski ponownie więc zapytał Mavrocordata o sprawę zniesienia zakazu przywozu polskich gorzałek. Kasztelan bracławski za przeszkodę w rozwiązaniu problemu uważał istnienie wśród bojarów przeciwnej temu

${ }_{97}$ Król do M. Grocholskiego, 25 VII 1782 (minuta listu), BCz, rkps 663, s. 403-405; król do K.J. Lipińskiego, 25 VII 1782 (minuta listu), BCz, rkps 671, s. 319.

${ }_{98}$ K.J. Lipiński do króla, 9 VIII 1782, BCz, rkps 671, s. 329.

99 K.J. Lipiński do króla, Kamieniec Podolski, 20 VIII 1782, BCz, rkps 671, s. 332.

100 M. Grocholski do króla, 4 VIII 1782, BCz, rkps 663, s. 417.

${ }^{101}$ M. Grocholski do króla, bez daty, BCz, rkps 663, s. 421. List został wysłany już po zakończeniu sejmiku poselskiego w Winnicy, a obrady przedsejmowe zwołano na 19 VIII 1782 r. Por. W. Filipczak, Życie sejmikowe, s. 86 .

102 Król do M. Grocholskiego, 3 IX 1782 (minuta listu), BCz, rkps 663, s. 423.

103 K.J. Lipiński do A. Cieciszowskiego, Żwańczyk, 20 XII 1782, BCz, rkps 671, s. 333.

${ }^{104}$ Ibidem, s. 334. 
grupy interesów. Proponował wprowadzenie przez Komisję Skarbu Koronnego zakazu importu wina z hospodarstwa, aby wywrzeć presję na Mołdawianach ${ }^{105}$. Tak więc opinia Grocholskiego, podobnie jak wcześniejsze uwagi Pichelsteina, zdaje się potwierdzać tezę Arapu o protekcjonistycznym podłożu polityki hospodarów mołdawskich ${ }^{106}$.

W maju 1783 r., jak podaje Arapu, do Mołdawii przybył Dzieduszycki. Tematem misji był eksport zboża z Polski i przywrócenie wolnego handlu wódkami. Pisarz wielki litewski powoływał się na skargi szlachty podolskiej w tej sprawie ${ }^{107}$.

Niezależnie od wspomnianych wyżej propozycji, sprawy mołdawskie w latach 1783-1784 budziły mniejsze zainteresowanie władz w Warszawie. Stanisław August i elity polityczne Rzeczypospolitej koncentrowały swoją uwagę na ułatwieniu zbytu polskich towarów, hamowanego przez politykę celną Prus ${ }^{108}, \mathrm{w}$ wyniku podjęcia inicjatyw dotyczących handlu chersońskiego. Do pomysłu spółki akcyjnej mającej prowadzić handel na tym obszarze starano się pozyskać najbardziej wpływowe postacie, m.in. majątkowego potentata, wojewodę ruskiego Stanisława Szczęsnego Potockiego ${ }^{109}$. W marcu 1783 r. powołana została na zjeździe w Winnicy Kompania Handlu Czarnomorskiego ${ }^{110}$. Istotne jest to, że w korespondencji króla z Grocholskim (odgrywającym istotną rolę w tworzeniu Kompanii) z maja-czerwca tego samego roku stosunki handlowe z Mołdawią są wyraźnie w cieniu problematyki handlu chersońskiego ${ }^{111}$. Przykładem wzrostu zainteresowania tym kierunkiem może być punkt podolskiej instrukcji poselskiej z sierpnia 1784 r., który został włączony z inicjatywy Onufrego Morskiego (przynajmniej sam tak twierdzil) ${ }^{112}$. Pisano w nim o potrzebie rozwinięcia handlu z Turcją ze względu na konieczność „spieniężenia produktów naszych krajowych”. Tranzyt przez porty tureckie miał uczynić tańszym import z Anglii, Francji i innych krajów. Postulowano więc wysłanie przez Polskę posła do Stambułu w celu zawarcia traktatu handlowego. Proponowano, aby w Akermanie lub innym porcie działał polski konsul, który miał zajmować się nadzorem nad przestrzeganiem planowanego układu ${ }^{113}$.

${ }^{105}$ M. Grocholski do króla, Hryców, 5 V 1783, BCz, rkps 663, s. 463-465.

106 V. Arapu, Componenta conflictuală, s. 86.

107 Idem, Relatiile comerciale, s. 130.

108 J.A. Wilder, Traktat handlowy, s. 192-193.

109 A. Dzieduszycki do S.S. Potockiego, 9 I 1783, CDIAU, F. 49, op. 2, sprawa 1866, k. 6-8. Na temat S.S. Potockiego por. E. Rostworowski, Potocki Stanistaw Szczęsny, [w:] PSB, t. XXVIII, s. 183-186.

110 M. Mądzik, Powstanie i pierwsze lata, s. 84-87.

111 M. Grocholski do króla, listy z okresu 15-29 V 1783 i król do M. Grocholskiego, 27 V i 11 VI 1783 (minuty listów), BCz, rkps 663, s. 451-472, 481-486. Por. też T. Srogosz, Między wojna a modernizacja, s. 217-218.

112 O. Morski do S.S. Potockiego, Rajkowce 18 IX 1784, CDIAU, F. 49, op. 2, sprawa 2180, k. 9v.

113 Ekstrakt $\mathrm{z}$ instrukcji danej posłom z województwa podolskiego na sejmiku dnia 18 VIII 1784 , CDIAU, F. 49, op. 2, sprawa 1557, k. 2. Sejmiki przedsejmowe zebraty się 16 VIII 1784 r., ale obrady w Kamieńcu były wyjątkowo burzliwe. Por. W. Filipczak, Życie sejmikowe, s. 124. 
W początkowym okresie działalności Kompanii Czarnomorskiej dał się zauważyć niedowład organizacyjny. Jesienią 1783 r. król wysłał jako swojego agenta handlowego Antoniego Zabłockiego (z czasem uzyskał rangę konsula), który dotarł do Chersonia dopiero wiosną kolejnego roku ${ }^{114}$. W tym czasie podejmowano także inne inicjatywy, mające ożywić handel czarnomorski. Sprawę stosunków handlowych z Mołdawią podniósł jesienią 1783 r. Onufry Bierzyński, kasztelan żytomierski. W listopadzie relacjonował królowi okoliczności związane ze swoją wyprawą czarnomorską ${ }^{115}$. Bierzyński uważał, że dla dużej części Ukrainy bardziej korzystnym niż Chersoń (dogodny dla powiatów: łuckiego i krzemienieckiego na Wołyniu, a także pińskiego i mozyrskiego w Wielkim Księstwie Litewskim) portem pośredniczącym w handlu czarnomorskim byłby mołdawski Gałacz. Odnosiło się to zwłaszcza do szlachty mieszkającej w oddaleniu od rzek Słuczy i Horynia, w województwach: kijowskim, bracławskim i podolskim ${ }^{116}$.

W połowie roku 1784 wyprawę do Turcji, mającą spowodować rozwój handlu, zorganizował Karol ks. de Nassau-Siegen, który w lipcu tego samego roku dotarł do Stambułu ${ }^{117}$. W drodze powrotnej książę przyjechał do Jass, gdzie prowadził rozmowy z hospodarem mołdawskim. Jak donosił Pichelstein, Karol ks. de Nassau-Siegen w liście do ambasadora Francji w Stambule pisał, że pod jego naciskiem Aleksander Mavrocordat I zgodził się na „pozwolenie importacyi wódek naszych do Mołdawii”118. Polski agent wątpił w prawdziwość tej informacji. Stwierdzał, że próby wwozu wódek podejmowane przez rosyjskiego konsula Severina nie zakończyły się sukcesem, choć uzyskał on początkowo zgodę na sprowadzenie niewielkiej ilości destylatów. Konsul musiał odstąpić od kontynuacji swych działań, gdyż hospodar uzyskał nowy ferman zakazujący importu gorzałki do Mołdawii. Pichelstein oczekiwał więc informacji, co mogło skłonić hospodara do zmiany stanowiska ${ }^{119}$.

Sprawa cofnięcia zakazu importu polskiej wódki do Mołdawii nie doczekała się jednak realizacji w czasach panowania „szalonego beja”. W styczniu 1785 r. polska placówka w Stambule nie zajmowała się nawet tą sprawą, lecz powiadamiała Departament Interesów Cudzoziemskich ofermanie do hospodara mołdawskiego w sprawie „zachowania jarmarków polskich pogranicznych"120. Interesowano się także ewentualnymi

${ }_{114}$ M. Mądzik, Z dziejów, s. 212-213; T. Srogosz, Zabezpieczenie militarne aneksji Krymu przez Rosje w 1783 roku na prawobrzeżnej Ukrainie, „Giłeja. Naukowyj wisnyk” 2015, Wypusk 97(6), s. 26. Sytuacja zmieniła się po reaktywowaniu kompanii w styczniu 1785 r., kiedy na jej czele stanął Prot Potocki. Por. M. Mądzik, Powstanie i pierwsze, s. 87-91.

115 O. Bierzyński do króla, Ludwipol, 9 XI 1783, BCz, rkps 655, s. 265-266; J. Reychman, Życie polskie, s. 186.

116 O. Bierzyński do NN, 15 XI 1783, BCz, rkps 655, s. 267-268.

117 S. Pichelstein do A. Dzieduszyckiego, Stambul, 11 VII 1784, AGAD, AKP, sygn. 83, s. 15-16; J. Reychman, Życie polskie, s. 114.

118 S. Pichelstein do A. Dzieduszyckiego, Stambul, 10 IX 1784, AGAD, AKP, sygn. 83, s. 44.

119 Ibidem.

120 S. Pichelstein do A. Dzieduszyckiego, Stambuł, 26 I 1785, AGAD, AKP, sygn. 83, s. 91-92. 
zmianami personalnymi w księstwach naddunajskich. Już w sierpniu 1784 r. musiały krążyć pogłoski o możliwości zmiany na tronie mołdawskim lub wołoskim. Pichelstein informował wówczas Warszawę, że władze tureckie znajdą zawsze przyczynę takiego $\mathrm{kroku}^{121}$. Niecałe pół roku później, w styczniu 1785 r., rzeczywiście doszło do zmiany władcy Mołdawii ${ }^{122}$. Dotychczasowego hospodara, aresztowanego i trzymanego w monasterze niedaleko Jass, zastąpił jego imiennik i stryjeczny brat. Jak twierdził wojewoda ruski i dowódca dywizji ukraińskiej i podolskiej, Stanisław Szczęsny Potocki, przyczyną upadku hospodara były działania rosyjskiego konsula Severina, z którym Aleksander Mavrocordat I miał nieustanne zatargi w sprawach handlowych ${ }^{123}$. Zdaniem Stourdzy, obok konfliktów z przedstawicielem Petersburga, hospodarowi zaszkodziły także złe relacje z Stefano Ignazio Raicevichem (Raicevici), austriackim konsulem w Jassach (hospodar uważał, że nie miał on formalnej akredytacji), co kosztowało „szalonego księcia” utratę poparcia dyplomacji rosyjskiej ${ }^{124}$. W opublikowanych przez Nicolae Iorgę ekstraktach listów, które dyplomaci pruscy wysłali do Berlina, pisano zarówno o rosyjskich skargach na postępowanie hospodara wobec ich konsula, jak i o żądaniach Wiednia pozbawienia tronu władcy Mołdawii. Pruski dyplomata akcentował też współdziałanie przedstawicieli dworów cesarskich ${ }^{125}$. Pichelstein informował, podobnie jak Potocki, o ciągłych zatargach hospodara z konsulem rosyjskim, które dotyczyły także rosyjskiego eksportu wódki. Do odwołania władcy Mołdawii miała przyczynić się też „insynuacyja” posła rosyjskiego Bułhakowa. Nowy hospodar, jak 10 lutego 1785 r. pisał polski agent, miał za kilka dni udać do Jass. Pichelstein twierdził, że Aleksander Mavrocordat II, syn byłego hospodara Jana, przebywając przez kilka lat jako więzień w Petersburgu, nauczył się języka rosyjskiego i nawet pobierał pensję z rozkazu Katarzyny II. Następnie stracił reputację wskutek małżeństwa z „komediantką”. Po powrocie z Rosji poślubił córkę (Zamfira Caragea) hospodara wołoskiego Mikołaja Caragei i został w Stambule dragomanem ${ }^{126}$. Według Stourdzy na tym stanowisku prezentował sympatie prorosyjskie i przyczynił się do zawarcia rosyjsko-tureckiego układu z 8 stycznia 1784 r., który potwierdzał cesję Krymu i Kubania (druga konwencja w Ainali Kawak) ${ }^{127}$.

${ }^{121}$ S. Pichelstein do A. Dzieduszyckiego, Stambut, 25 VIII 1784, AGAD, AKP, sygn. 83, s. 33.

122 Według: Acte şi fragmente, t. II, s. 190 (Diez do Fryderyka II, Konstantynopol, 26 I 1785), Aleksander Mavrocordat I utracił tron już 12 I 1785 r.

${ }_{123}$ S.S. Potocki do króla, Tulczyn, 6 II 1785, BCz, rkps 735, s. 839. Potocki kupił dowództwo dywizji pod koniec 1784 r. od kasztelana kijowskiego Józefa Stempkowskiego. Por. A. Kamińska, Stempkowski (Stępkowski) Józef Gabriel, [w:] PSB, t. XLIII, s. 388.

124 A. Stourdza, L'Europe orientale, s. 244-245. Na temat Raicevicha por. V. Arapu, Problema relațiilor comerciale dintre Țara Moldovei şi Polonia în a doua jumătate a secolului al XVIII-lea reflectată in izvoarele istorice ale epocii, „Studia Universitatis Moldaviae” 2017, nr 10(110), s. 131.

125 Acte şi fragmente, t. II, s. 190 (Diez do Fryderyka II, Konstantynopol, 26 I 1785).

126 S. Pichelstein do A. Dzieduszyckiego, Stambut, 10 II 1785, AGAD, AKP, sygn. 83, s. 102.

127 A. Stourdza, L'Europe orientale, s. 255-256. Treść traktatu w tłumaczeniu na język polski została opublikowana w: Traktaty między mocarstwami europeyskimi od roku 1784 zaszte [...], wyd. F. Siarczyński, 
Z listu Potockiego wynika, że zmiana na tronie ożywiła w Polsce nadzieję na przywrócenie eksportu wódki do Mołdawii. Jak powiadomił króla wojewoda ruski, w lutym 1785 r., spora ilość alkoholu została wówczas przewieziona przez granicę, ale „pod imieniem towaru rosyjskiego" ${ }^{28}$. Pichelstein, po uzyskaniu przez hospodara inwestytury, kilka razy negocjował sprawę przywozu polskich gorzałek. Przedstawił mu kopię memoriału złożonego Porcie i namawiał władcę Mołdawii, by skłonił Turcję do cofnięcia wydanych w tej sprawie fermanów, co nowy hospodar obiecał uczynićn ${ }^{129}$. Stanisław August, choć był zadowolony z szansy na wznowienie eksportu, żałował jednak obalonego hospodara. Aleksander Mavrocordat I według Stanisława Augusta „z inszych miar pokazywał się przychylniejszym dla Polski” niż jego poprzednik ${ }^{130}$. Ostatecznie Aleksander Mavrocordat II i jego następca Aleksander Ipsilanti (1786-1788) ${ }^{131}$ nie znieśli wspomnianego zakazu. Interwencje władz polskich miały miejsce jeszcze w 1787 r., kiedy Komisja Skarbu Koronnego wysłała Tadeusza Czackiego jako specjalnego wysłannika mającego negocjować sprawy handlowe z Aleksandrem Ipsilanti (ważnym tematem był import do Polski soli), ale i one nie przyniosły rezultatu w sprawie sprzedaży w Mołdawii polskiej wódki ${ }^{132}$. W tym czasie sprawa zeszła już na dalszy plan, ponieważ opinia publiczna interesowała się bardziej perspektywami handlu chersońskiego, a następnie konfliktem rosyjsko-tureckim.

Polityka dworu warszawskiego wobec Mołdawii zasługuje na uwagę ze względu na nietypowe kanały służące wzajemnej komunikacji. Posługiwano się nie tylko nieoficjalnymi reprezentantami Rzeczypospolitej w Stambule (Dzieduszycki, Pichelstein) czy komendantem twierdzy kamienieckiej (gen. Witte), co było już dobrze znane historykom. W początkach 1785 r. o sytuacji w hospodarstwie dość szczegółowo informował króla wojewoda ruski Potocki, ówczesny dowódca dywizji ukraińskiej i podolskiej. W prowadzeniu działań dyplomatycznych korzystano też z pomocy czołowych przedstawicieli stronnictwa dworskiego na terenach graniczących z hospodarstwem (województwa bracławskie i podolskie). Byli nimi kasztelan Grocholski i podkomorzy Lipiński, którzy posiadali własne kontakty w Jassach i mieli wiedzę o rozwoju sytuacji w Mołdawii. Cieszyli się na tyle dużym zaufaniem monarchy, że powierzał im zadania z pogranicza dyplomacji, choć realizowane według dokładnych wskazówek dworu (formularze

t. VI, Warszawa 1790, s. 1-11 (Traktat konstantynopolitański wr. 1784). Por. też Z. Anusik, France in Sweden's Foreign Policy in the Era of Gustav III's Reign (1771-1792), Łódź 2016, s. 96.

128 S.S. Potocki do króla, Tulczyn, 6 II 1785, BCz, rkps 735, s. 839.

129 S. Pichelstein do A. Dzieduszyckiego, Stambuł, 10 II 1785, AGAD, AKP, sygn. 83, s. 102-103.

${ }_{130}$ Król do S.S. Potockiego, 13 II 1785 (minuta listu), BCz, rkps 735, s. 844-845.

131 O roli rodziny Ipsilanti (Ypsilantis) w księstwach rumuńskich w tym czasie polski czytelnik może przeczytać w artykule, który napisał Vlad Mischevca, historyk mołdawski: W. Miskewka, Książe Konstantyn Ipsilanti w kontekście kwestii wschodniej: o niektórych aspektach dziatalności dyplomatycznej na przetomie wieku XVIII i XIX, „Wschodni Rocznik Humanistyczny” 2014, t. X, s. 199-200.

132 J. Reychman, Zatarg handlowy, s. 221-222; V. Ciobanu, Aspecte ale relațiilor, s. 135. 
listów, które powinni wysłać do hospodara). Nie wydaje się jednak, by sugestie, które przesyłali do Warszawy miały poważniejszy wpływ na politykę prowadzoną na tym obszarze przez Rzeczpospolitą.

\begin{abstract}
The conflict over trade between Poland and Moldavia in the 80 s of the $18^{\text {th }}$ century has already elicited interest of historians from Poland, Romania and Moldova. The contributions of Jan Reychman, Veniamin Ciobanu and Valentin Arapu are particularly relevant but they do not exhaust the analyzed topic. The time-frame of the article is 1780-1785 although the origin of the conflict dates back to 1778 when Constantin Moruzi forbade the import of Polish vodka to Moldavia. The year 1785 accepted as the final element in the time-frame does to mean that the conflict came to an end then. After Antoni Dzieduszycki had left Istanbul in 1780, the Polish affairs were taken over by Stanisław Pichelstein, whose official role was that of translator (dragoman) and Head of School of Oriental Languages. The article ends with the accession to the throne of Alexandru Mavrocordat II, who succeeded Alexandru Mavrocordat I; the ensuing response of the Polish political elite to this event is also analyzed. The sources that constitute the basis for the analysis come from The Central Archives of Historical Records in Warsaw, and they include the correspondence of Pichelstein with Stanisław August's cabinet and Department of Foreign Affairs of the Permanent Council. Another important source that has not been used so far is Stanisław August's domestic correspondence from the Princes Czartoryski Library in Cracow. It shows how the Polish court tried to make use of the contacts established with hospodars by the high-ranking officials from the voivodeships bordering on Moldavia (i.e. the voivodeships of Braclaw and Podolia) who made demands on Jassy. On behalf of the nobility in their voivodeships, the aforementioned officials demanded that restrictions on the vodka trade should be lifted. This was done in strict agreement with the recommendations from Warsaw.
\end{abstract}

\title{
Keywords
}

Poland in $18^{\text {th }}$ century, Moldavia in $18^{\text {th }}$ century, trade between Poland and Moldavia, Stanisław August Poniatowski, Constantin Moruzi, Alexandru Mavrocordat I.

Translated by Dorota Filipczak 